\title{
Storm i kaffekoppen
}

Annonsene i Tidsskriftet skal være saklige, pålitelige og opplysende. Så streng har man ikke alltid vært. | Tidsskriftet nr. 22/1938 lokker produsenten med gratisprøver for å få legene til å anbefale et kaffeerstatningsmiddel (Tidsskr Nor Lægeforen 1938; 58: mot s. 1303). Og det er ikke bare til å le av - i utformingen har man skjelt sterkt til Egedius' Seidmennene på Skratteskjær, og de fikk jo en trist skjebne.

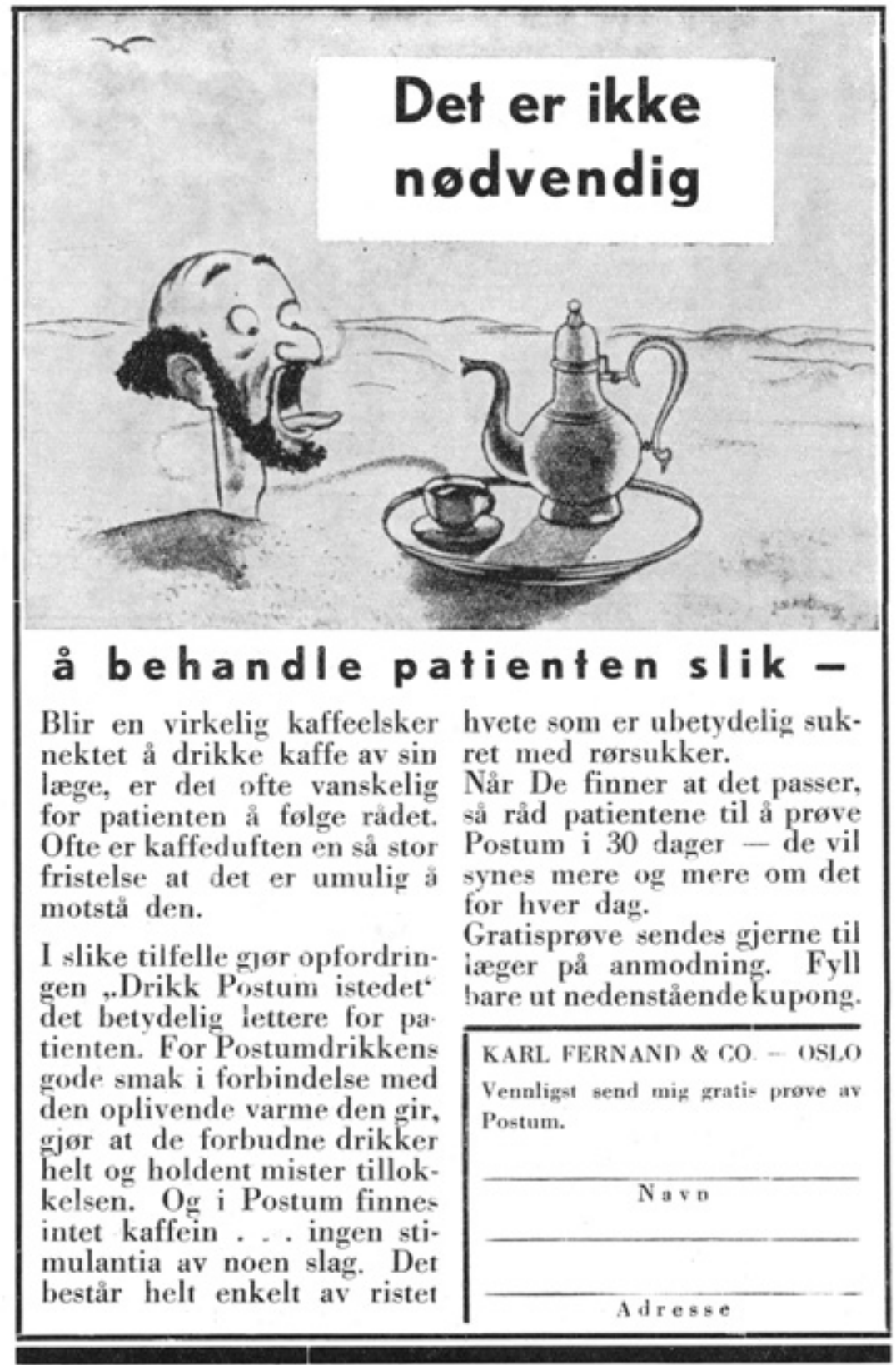

